\title{
Private International Law
}

\author{
Antisuit injunctions: Airbus Industrie GIE v Patel \\ by Olusoji Elias
}

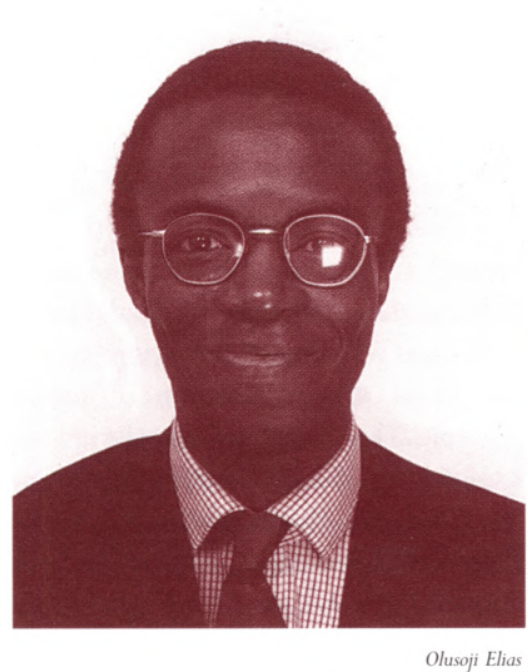

The leading opinion of Lord Goff in Airbus Industrie GIE v Patel [1999] AC 119 ('Airbus') states the law on transnational antisuit injunctions as it stands today, complete with the bonus of a given set of facts. Although his Lordship's opinion distinguished the 'alternative forum' (as distinct from 'single forum') circumstances in to case, his clarification of the law, to which the other members of the House acceded, makes it unlikely that the law can foreseeably be radically different.

It is particularly edifying to study the decision because of the practical importance of antisuit injunctions in transnational litigation. They are not part of the expressed scheme of the Brussels Convention, as was made clear by the European Court of Justice in Overseas Union Insurance Ltd $\mathrm{v}$ New Hampshire Insurance Ltd Case C-351/89 [1991] ECR I-3317 at p. 3350, para. 23; [1992] QB 434 (but see the subsequent Court of Appeal decision in Continental Bank NA v Aeakos Compania Naviera SA [1994] 1 WLR 588 concerning parallel proceedings in England and Greece, where an injunction based on vexation and oppression was, in fact, granted to restrain the foreign proceedings), nor are they entirely exceptional (Tracomin SA v Sudan Oil Seeds Co Ltd (No. 2) [1983] 1 WLR 662). The availability of such suits must involve some measure of intervention in the relevant foreign jurisdiction.

\section{THE FACTS AND RULING}

The Airbus facts began with an aircraft crash in Bangalore, India, in which the British plaintiffs were severely injured or bereaved. The cause of the crash was established in India as airline pilot error, with the result that Indian damages were recovered against the airline company, but not against the airport authority concerned because the injuries or deaths could not be said to have been caused by its employees' negligence.

At the time of having begun the Indian claim, the plaintiffs also started an action for damages in Texas, mainly against Airbus, the Toulousian designers and builders of the aircraft (the defendants in the subsequent English claim), who were subject to that jurisdiction by reason of having transacted business with a Texan company in the past.

To counteract the Texan proceedings, Airbus successfully sued in India to have the Texan, and any other non-Indian, proceedings discontinued. However, the injunction obtained in India was not capable of extraterritorial enforcement in Texas. Therefore Airbus sued in England to enforce the Indian injunction because, among other reasons advanced on their behalf, it would be vexatious or oppressive for the Texan action to persist. At first instance, Colman J declined to enforce the Indian injunction or to grant an English one to restrain the Texan suit respectively, because the former was not a money judgment in personam (see, e.g. Beatty v Beatty [1924] $1 \mathrm{~KB}$ 807) as is required under the Administration of Justice Act 1920 or the Foreign Judgments (Reciprocal Enforcement) Act 1933, and England was not for um conveniens in the sense of being the most appropriate forum.

This latter finding was reversed by the Court of Appeal, led by Hobhouse LJ, in the interests of justice between parties properly subject to forum jurisdiction. The wronged parties then appealed to the House of Lords. The main aspects of adjudication in their Lordships' House were as follows:
- The injured parties had appealed to the House of Lords on the point that, even if England was non conveniens as to the merits (while India was), the English forum was nevertheless jurisdictionally competent to intervene between the respective other fora by restraining the Texan claim in order to enable recognition and enforcement of the Indian orders.

- The Texan proceedings, inter alia for substantial punitive damages coupled with a contingency fees arrangement, concerned product liability and negligent training of the pilots. On appeal to the Texas Court of Appeals from the Texas State District Court, Airbus had unsuccessfully sought to resist the jurisdiction of the Texan courts on the ground that it was for the most part government-owned and therefore protected under the US Foreign Sovereign Immunity Act 1976, and was looking to make further appeal to the Texas Supreme Court at the time of their Lordships' adjudication in England.

- The doctrine of forum non conveniens was not accepted in Texas at the time of the case (although it is recognised, e.g. in the Restatement of the Law Second: Conflict of Laws 1980, Vol. 1, para. 84, and in Piper Aircraft Co v Reyno 454 US 235 (1981)). It has now been incorporated. Original jurisdiction had been acquired in Texas on the apparent basis of strict liability. This would not have affected subsequent recognition and enforcement in England. Much in the vein of a trial on the merits at the interlocutory stage, Hobhouse LJ had held that the claim would likely have been deemed to be without sufficient justification if it had been pursued in a fault liability jurisdiction like England.

- Colman J's 'balance of convenience' reasons for declining jurisdiction: if Airbus was liable in Texas, it would need to have the matter of its liability in the Indian court reopened in order to recover contributions from the airline and the airport authority in Texas. The Indian proceedings would 
probably have continued because no injunction was sought by the claimants in Texas. Conflicting decisions could therefore be reached if an English injunction was granted. Furthermore, Airbus had not proved that Texan proceedings were vexatious or oppressive so as to justify an English injunction to restrain.

- Hobhouse LJ's leading judgment as to (a) forum interest or interventionism outwith the preservation of its own process and (b) the availability of an injunction for the purpose: applying the Privy Council's finding in Société nationale industrielle aerospatiale v Lee Kui Jak [1987] 1 AC 871 ('SNIA') (which has remarkably identical facts to those in Airbus) that the protection of own process does justify forum interventionism, his Lordship discountenanced Colman J's finding that clear oppression alone could found the type of injunction sought. Further, with India as the natural forum and France as another appropriate forum, Texan suit was ostensibly oppressive because it was clearly inappropriate, as well as potentially and possibly prejudicial to Airbus.

- Common law principles governing the grant of an antisuit injunction (SNIA, the resolution of clashes between jurisdictions, and the scope for comparativism): these are derived from jurisdiction over the defendant subject to the practical, but undeniably imperfect, principle of forum non conveniens. In sum, the natural forum for a dispute justifies trial being remitted there, because to do otherwise would be unjust to the defendant and would not further the equities in the claim. Further, the independence of self-restraining jurisdictions, together with the principles of comity, are to be observed. In other words, if England is a contestable forum in a particular claim, an antisuit injunction would be available if the English forum was the natural forum according to its own law (SNIA, at p. 896).

- Comity: referring to the contest of, and for, antisuit injunctions as between the English and the District of Columbia jurisdictions surrounding British Airways Board v Laker Airways Limited ([1985] AC 58), in which the House of Lords held that no antisuit injunction ought to have been granted by the Court of Appeal, Lord Goff makes clear that the protection of forum interest should be combined with the observance of forum public policy, as was emphasised by Judge Wilkey in the District of Columbia Court of Appeals in Laker Airways Limited v Sabena Belgian World Airlines (731 F. 2d 909 (1984) at pp. 926-927). In particular, he stated (at p. 698) that:

'[a]s a general rule, before an anti-suit injunction can properly be granted by an English court to restrain a person from pursuing proceedings in a foreign jurisdiction in [alternative forum cases], comity requires that the English forum should have a sufficient interest in, or connection with, the matter in question to justify the indirect interference with the foreign court which an anti-suit injunction entails.'

The judgment is much a state-of-theart elucidation of the law on this type of injunction. Implicitly, the role of comity in 'single-forum cases' is much reduced in considering the grant of these injunctions, that 'any limiting principle requiring respect for comity cannot simply be expressed by reference to the question whether the English court may be the natural forum for the dispute' ( $p$. 698-699; cf. Sopinka J in Amchem Products Inc and Others v Workers' Compensation Ltd 102 DLR (4th) 96 (1993), especially at pp. 118-121).

\section{BROADER ISSUES}

It is perhaps in place to consider some issues which run with a broader framework for the decision:

- There is the unavoidable basic requirement that properly exercisable jurisdiction, and with it issues of forum conveniens, be had before an antisuit injunction can be granted. The English forum could effectively query the exorbitant exercise - based on a tenuous link with Airbus (France) - of Texan jurisdiction and consequently refuse to recognise the decision of that forum. Comity considered, to do otherwise must go to the view the forum takes of the Indian decision, which of itself could not prevent the Texan proceedings, and, ultimately, to the doing of substantive justice as between the parties.

- With reference to Texan jurisdiction, which was not concerned with res judicata, there seems little reason of principle why the forum's own view of substantive justice between the parties could not be deemed to be sufficiently compelling to justify interventionism this side of applying Texan law, if the Texan proceedings could properly have been continued.

- Because Airbus and the British claimants were parties domiciled within the territorial reach of the Brussels Convention, even though the place in which the tragic mishap occurred was well beyond, a view of the question of the proper forum, in compliance with the allocation of jurisdiction under the Brussels Convention, would be that France is the only place in which the litigation should take place in Europe. This would also comply with the requirements of s. 49 of the Civil Jurisdiction and Judgments Act 1982 (as amended), by which the English forum can apply the doctrine of forum non conveniens as long as doing so may not be deemed to be contrary to the convention.

- It is arguably ripe for fuller consideration that non-money judgments in personam be recognisable and enforceable between jurisdictions, after the Brussels Convention and status judgments respectively, not least because what is to be enforced is res judicata in every decision that succeeds, jurisdictionally speaking, according to the law of the forum in which recognition and enforcement is sought and, perhaps less rigorously, because it is increasingly to be seen that the quality of applicable law in most jurisdictions (in Airbus, it was India) is credibly regular, or at least visibly more so than it is as between the legal systems of the European Union (where system difference is pronounced, at least between England and civil law jurisdictions) and yet of ostensibly little consequence to harmonisation through cross-enforceability under the permissive, rather than authorising, art. 24 and 25 of the Convention.

- The use of these provisions by the fora is cautious, so as not to undermine the harmonising system of the Convention as a whole, e.g. by imposing common, instead of national, interpretation on the terms, as in the French case of Menegatti v Societe Mettalurgica Nava Stefano e Giuseppina (Paris, 17.11.1987, 
Clunet 96, note Huet). In that case, the Paris Court of Appeal appears to have held that interim measures sought in respect of a case concerning the termination of an exclusive commercial agency agreement, containing an Italian exclusive jurisdiction clause, between an Italian plaintiff resident in France and an Italian company, were measures best applied by the courts of the contractual jurisdiction.

\section{FURTHER READING}

See Issue 14 (February 1999), p. 13, for another article on proper jurisdiction (the Pakistan National Shipping case) by Olusoji Elias. An article on transatlantic litigation in the Bijlmer air crash case, by Fred J Bruinsma and Leny E de Grootvan Leeuwen, appeared in Issue 21 (October 1999), p. 23.

- The globalisation of civil justice requires universal acceptance of the bases upon which any forum acquires or must decline jurisdiction. That a forum which is insufficiently interested in a given cause can nevertheless take jurisdiction and apply the law of the natural forum on restraint of foreign suit is commendable but absent from the common law because the jurisdictional issues arising are procedural. This idea is much less defensible at present than the basis described under the next point.

- It is necessary to individuate the comparable law under the Brussels Convention, since antisuit injunctions are not part of its scheme for the acquisition or declination of jurisdiction. The difficulties and consequences of a divergence of approach between English law and the civil-law-generated Brussels Convention - in particular the possibility of injustice from the rigidity of the defined conflict-avoiding jurisdictional rules of the latter which ostensibly avoid the flexible and practical doctrine of forum non conveniens - were broached by Lord Goff in the Airbus case (at p. 692). A basic theme of the Brussels Convention is that the jurisdictions concerned are inter-dependent rather than emphatically autonomous (pp. 697-698, and in his Lordship's postscript at p. 701); therefore, resolution of jurisdictional conflicts arising in connection with concurrent litigation in the fora of more than one convention country depends on which court was first seised of the given matter, rather than on considerations of which forum is most appropriate. The common theme is of forum restraint by way of rules on the declining of jurisdiction or the staying of actions.
- It is important that parties in transnational litigation should be encouraged accurately to predetermine the forum whose jurisdictional competence is to be prayed in aid of disputes arising between them. This facilitates settlement of the primary question of original jurisdiction and the different, but no less consequential matter, of the exercise of competence elsewhere such as might subsequently become necessary.

\section{CONCLUSION}

A different composite of facts yet to arise could enlarge the foregoing analysis from Airbus, particularly as to the enduring value of the doctrine of forum non conveniens outside the scheme of a multilateral jurisdiction and judgments convention. Further deliberation of jurisdictional autonomy must depend on more general transnational judicial jurisdiction beyond the immediate scope of antisuit injunctions. (c)

\section{Olusoji Elias}

Member of the International Bar Association

Olusoji Elias is the author of Judicial Remedies in the Conflict of Laws (forthcoming).

\section{What makes a good}

lawyer an expert?

\section{Legal information as it happens}

- Proactive Daily Digest Service

- Selects, edits and delivers on the same day as judgment

- Cross-referenced and indexed database of judgments

\section{Fourth Floor, Quality House, Quality Court, Chancery Lane, London WC2A 1 IIP Tel: 01714055434 Fax: 01714055693 E-Mail: info@newlawonline.com Website: http://www.newlawonline.com}

